\title{
Fenomén fikcie v dejinách Kremnice
}

\author{
DANIEL HAAS KIANIČKA
}

\section{NBS - Múzeum mincí a medailí Kremnica}

\section{Phenomenon of fiction in the history of town Kremnica}

Abstract: Subject of fiction has become a permanent part of humanities research in the recent decades. Philosopher Alexius Meinong wrote that our cognition of objects does not depend on their real existence. Our mind reacts to thoughts, desires and feelings as well. A man is surrounded not only by real, but also by imaginary entities. The issue of the fiction theory had also been a research subject of some other philosophers, sociologists and literary scientists. There are many types of fiction. One of them is a literary fiction, which in the case of Kremnica can be studied through works written by Ján Kollár or Jozef Cíger Hronský. Fiction in the form of a game or prank had also been an important phenomenon in the history. There had been many associations in the world based on the principle of fiction. In Kremnica, this type of association is represented by the Casino association and its Book of Swamps (Sumpfbuch) with fictitious names of members of the association and a number of fictional stories. Mythology related to the world of fictitious mining ghosts had also played a role in the environment of the town Kremnica. It is interesting that history itself can be presented with the help of fiction, as Barbara Balážová showed in her book Pictorissa Cremniciensis. In the first part, she had created a fictitious diary of Kremnica painter Johanka Emerencia Rothenstein (beginning of the $18^{\text {th }}$ century). Fiction had also been used as a part of national revival efforts. In Kremnica, this phenomenon is represented by the existence of a fictitious "ancient" inscription on the hill Velestúr. It is important to know that through fiction it is possible to develop the imagination, analogous and logical thinking and creativity of man.

Keywords: fiction, theory of fiction, literary fictive worlds, fiction as a game and prank, activities of burgess societies, miner`s mythology, educative fiction, fiction and a national narrative, creative function of fiction.

DOI: https://doi.org/10.24040/ahn.2020.23.02.147-166

Motto:

Vel'mi dobre viem, ako nesmierne miluješ nič nie však pre jeho zanedbatel'nú cenu, ale pre pôvabnú l'ahkost' a veselú hravost', ktorú to slovo ponúka.

Johannes Kepler, $1611^{1}$

${ }^{1}$ Pozri: KEPLER, Johannes: O šestiúhelné sněhové vločce. Poutavé čtení o „ničem“. Praha : MatfyzPress, 2016, s. 7. 


\section{Úvod}

Problematika fikcie sa v posledných desat'ročiach stala pevnou súčast'ou skúmania humanitných vied. Z pohl'adu filozofie je tematika pomyselných súcien tak súčast'ou ontologickej, ako aj analytickej filozofie. V spojitosti s fikciou sú vel'mi podnetné napríklad Meinongove a Searlove filozofické reflexie.

Alexius Meinong vo svojom diele o teórii objektu (The Theory of Objects, 1960) hovorí o tom, že súčast'ou nášho poznávania sú tvrdenia o veciach (objektoch) bez ohl'adu na ich ontologickú existenciu. Naše vedomie vytvára pojmy nielen na základe zmyslovej recepcie, ale aj na základe reprezentácií, myšlienok, túžob a pocitov. Tie odrážajú svet objektov (predmetov), ktoré však nemusia byt' fyzickými telesami. Alexius Meinong v tejto súvislosti zaviedol pojem tzv. intencionálneho objektu, ked' každému psychickému aktu (myšlienke, túžbe zodpovedá určitý „objekt“, ktorý „existuje“. Skúsenost' pozostáva z reflexie existujúcich vecí, ale aj z akceptácie pomyselných súcien, na ktoré poukazujú naše mentálne akty. Meinong rozoznáva reálne existujúce objekty poznávané na základe empírie a tvrdenia, ktoré niečo označujú, no v reálnom svete im nezodpovedajú žiadne fyzické telesá. Ide o fiktívne a nemožné predmety (zlatá hora, okrúhly štvorec, údolie bez vrchov). Úlohou Meinongovej teórie objektov je možnost' posúdenia pravdivosti či nepravdivosti v prípade nereálnych objektov - intencionálnych pomyselných objektov. Aby sme v prípade uvedeného príkladu zlatej hory mohli vyrieknut' pravdivý alebo nepravdivý súd (hora vyzerá ako zo zlata, pretože je zložená z určitého žltého lesklého materiálu), resp. uzáver, že neexistuje (existencia zlatej hory nie je možná), musí táto hora existovat' minimálne ako intencionálny objekt $\mathrm{v}$ našom vedomí. ${ }^{2}$

Ďalšia z teoretických reflexií sa nazýva pragmaická teória, ktorá vychádza z úvah Johna R. Searla o úlohe fikcie v poznávaní človeka (Expresion and Meaning. Studies in the Theory of Speech Acts, Cambridge 1979). Podl'a nej je jazyk, ktorý používame natol'ko plastický, že umožňuje skúmat' nielen empirický svet, ale aj sémantickú povahu pojmov a zámery v pozadí komunikácie. Práve odhal'ovanie motivácií rečových aktov umožňuje poznávat' dôvody používania fikčných foriem majúcich, a to nielen v kontexte umenia, schopnost' niečo zvýraznit'. Napríklad, nie všetky historické diela, $v$ ktorých existujú entity majúce povahu výtvoru dobovej predstavivosti možno považovat' za súčast' umeleckej

\footnotetext{
2 JENÍK, Lukáš: Niektoré perspektívy a výzvy filozofického skúmania fikcie. In: Studia Aloisiana, roč. 4, č. 2, 2013, s. 5-10. [online]. Dostupné na internete: <http://studiaalo isiana.tftu.sk/wp-content/uploads/2013/07/Luk\%C3\%A1\%C5\%A1-Jen\%C3\%ADk-Niek tor\%C3\%A9-perspekt\%C3\%ADvy-a-v\%C3\%BDzvy-filozofick\%C3\%A9ho-sk\%C3\%BAma nia-fikcie.pdf> [Cit. 2016-11-07].
} 
literatúry (literatúra je naratívna a pracuje s fikčnými svetmi) a ani výskyt fiktívnych entít v týchto dielach nemusí znamenat', že ide o fikciu. Ide, okrem iného, aj o stredoveké beštiáre. Jednorožce či fénixovia sa v nich pokladali za reálne existujúce bytosti a mali rovnaký ontologický status ako v prírode existujúce zvieratá a vstupovali do kauzálnych súvislostí v rámci reálneho sveta. Beštiáre nevznikali ako fikcie (fabulácie), ale boli výsledkami odborných skúmaní v rámci dobových kritérií vedeckosti. Sú teda historickými vedeckými spismi, no aj fikciami z dnešného pohl'adu umeleckej literatúry. Fikčné svety sa v tejto spojitosti interpretujú úplne rovnako ako faktické tvrdenia, avšak o nefaktických entitách a vzt'ahoch. Podl'a Johna R. Searla je fikcia osobitnou kategóriou tvrdenia, ktoré nie je odlišné v zmysle doslovnosti (mnohé fiktívne príbehy charakterizuje doslovný a realistický jazyk príbehu, hoci, prirodzene, majú nevážny charakter na rozdiel od faktu; napríklad fiktívny detektív Sherlock Holmes by mohol byt' pre neznalých skutočnou historickou postavou), ale v rovine pragmatického jazyka - od vážneho (i úplne klamlivého) tvrdenia ho odlišuje aktivita predstierania. Nejde teda o zavádzanie, ale o hru, na ktorej sa zúčastňuje autor i adresát fikčného deja. Autori fikcie sa nás na rozdiel od faktografických tvrdení neusilujú presvedčit' o existencii fiktívnych entít mimo ich fikčných svetov (napríklad spomenutý Sherlock Holmes). ${ }^{3}$ Prirodzene, situácia sa komplikuje v prípade, ak niekto fikciu prezentuje ako skutočnost', teda pri fikčnej hre vlastne „hrá“ iba jedna zo strán. Z uvedených skutočností vyplýva, že fiktívne postavy a príbehy napriek svojej nefaktickosti reálne ovplyvňujú naše myslenie i konanie. Fikcia môže mat' dôležitú informatívnu a edukatívnu hodnotu. Pôsobí pozitívne na rozvíjanie predstavivosti, fantázie a analogických schopností v rámci spoločenských vzt'ahov. Negatívom „nepochopenej“ fikcie je skreslené podávanie informácií o osobách a veciach.

Pri tom všetkom je potrebné zdôraznit', že aj fiktívne, či fikčné svety musia mat' svoju vnútornú koherenciu - držia sa určitých pravidiel, aby vich existenciu ako paralelných fiktívnych svetov bolo možné uverit'. To, prečo skúmame fikciu (veda), má pôvod v schopnosti fikčných svetov formulovat' motívy aktuálneho sveta v paralelnom obraze umenia (ale aj vedy). Tým sa rozvíja kreativita a logické myslenie človeka. Viac, ako o pravde vo fikcii, tak možno hovorit' o pravde prostredníctvom fikcie. Fikčný svet môže akcentovat' niektoré v realite prehliadané skutočnosti, resp. zvýrazňovat' určité aspekty reality. Kontrast reality a fikcie nás učí nielen predstavivosti, ale takisto posilňuje našu schopnost' neopierat' sa pri posudzovaní vecí len o presvedčenie a požadovat'

3 JENÍK, L.: Niektoré perspektívy..., s. 11-16. 
aj rozumové zdôvodnenia. ${ }^{4}$ Ak to zhrnieme, tým, že pri myslení zohl'adňujeme aj fiktívne entity, prepožičiavame im punc „reality“ - reálne môžu ovplyvnit' naše skutky. Ked'že aj fikcia má určitý ciel' či poslanie a ovplyvňuje nás, stáva sa reálnou historickou udalost'ou. Je napríklad svedectvom úsilia niektorých vlasteneckých vzdelancov 19. a 20. storočia o zdôraznenie historických nárokov a práv svojho národa na dané štátne územie.

K podobným záverom možno dospiet' aj pri skúmaní falzifikátov či konšpiračných teórií. Napríklad sociológ Niklas Luhmann rozvinul $\mathrm{v}$ jednej zo svojich prác systémovú teóriu popisu sociálnych mechanizmov (Soziale Systeme: Grundriß einer allgemeinen Theorie, 1984). Jej základom je chápanie komunikácie ako prelínania aktivít medzi odosielatel’om a príjemcom. Prvý oznámi druhému určitú informáciu, pričom nejde len o jednoduché oznámenie zmyslových dát, ale aj o porozumenie obsahu informácie. Tak vzniká spätná väzba, ktorá sa realizuje v nasledujúcej komunikácii. Peter Deutschmann aplikoval túto teóriu v praxi, a to na známe české falzifikované rukopisy - královedvorský a zelenohorský. V štúdii Mystifikace z prvního až n-tého stupně z roku 2014 píše, že dôležitá pri oznámení o existencii rukopisov nie je ani tak skutočnost', či sú rukopisy autentické, ale fakt, že medzi odosielatel'om a prijímatel'om oznámenia došlo ku komunikácii, a to už od aktu porozumenia informácii. Podstatné je, že príjemca pochopil niečo ako stredoveký text. Protikladom k tomu by teda nebola identifikácia pravosti rukopisov, ale ich „neobjavenie“. Porozumenie tvorí komunikácia a mení stav príjemcu. Či už veríme v autenticitu rukopisov alebo nie, informácia o ich existencii nás zmenila - vyvolala komunikáciu, teda polemiky, ktoré trvajú vlastne až dodnes (diskusia o rukopisoch). Systémovú teóriu v zásade nezaujíma otázka pravosti rukopisov, ale zdôrazňuje spoločenskú relevanciu komunikácie - mystifikácia v tomto prípade bezpochyby predstavuje komunikačnú prax, ktorej sociálna relevancia (dopad na spoločnost') je vel'mi vysoká. ${ }^{5}$ Zhrnút' to možno tak, že mystifikácia patrí v tomto konkrétnom prípade jednoznačne do dejín národného obrodenia. Stala sa „skutočnou“ historickou udalost'ou, ktorá zmenila českú kultúru a spoločnost'.

To isté platí aj pri konšpiratívnych teóriách, ktorých obsah je „nereálny“, no ich vzt'ah k skutočnosti v rámci komunikácie je „reálny“. Umberto Eco v jednej zo svojich esejí o konšpiráciách citoval slová filozofa a sociológa Georga Simmela o tom, že „tajomstvo prepožičiava svojim

\footnotetext{
${ }^{4}$ JENÍK, L.: Niektoré perspektívy..., s. 20-22.

5 DEUTSCHMANN, Peter: Mystifikace z prvního až n-tého stupne. In: HRDINA, Martin PIORECKÁ, Kateřina (eds.): Historická fikce a mystifikace v české kultuře 19. století. Praha : Academia, 2014, s. 29-31.
} 
majitel'om výlučné postavenie [...] Je v zásade nezávislé od svojho obsahu, ale v každom prípade tým účinnejšie, čím širšie a významnejšie je jeho vlastníctvo... spoločným účelom je [...] posilnit' neznámo prostredníctvom predstavivosti a prisúdit' mu takú váhu, ktorá nie je zjavným skutočnostiam vyhradená." Eco tento citát komentuje slovami: „Paradoxným dôsledkom toho je, že za každým falošným sprisahaním sa možno vždy skrýva sprisahanie niekoho, v záujme ktorého je prezentovat' nám falošné sprisahanie ako niečo skutočné." Napokon Eco svoj text uzatvára glosovaním myšlienky vykonšpirovaných konšpiračných teórií Noama Chomského: „Z fantazírovania o zdanlivom sprisahaní najviac profitujú práve inštitúcie, ktorým chcú konšpiračné teórie uškodit'. Napríklad, ked' si predstavíme, že George Bush zavinil útok na dvojičky a ich likvidáciu, pretože chcel tak ospravedlnit' zásah v Iraku, začíname sa pohybovat' medzi preludmi a prestávame analyzovat'skutočné dôvody, ktoré viedli k útoku na Irak, to zvádza k podozreniu, že informácie o Bushovom sprisahaní rozšíril sám Bush..."6 Fikcia, mystifikácia, fantazírovanie a konšpirácia tak bez ohl'adu na svoj vzt'ah k realite vytvárajú také množstvo spletitých komunikačných vzt’ahov, že tie vyvolávajú reálne reakcie prijímatel'ov informácií o fiktívnych entitách.

Vo filozofii a sociológii fikcia predstavuje „skutočnú“ entitu, pretože reálne dokáže ovplyvňovat' naše myslenie a skutky, hoci reprezentuje neexistujúce udalosti, veci a vzt'ahy. Fikcia sa tak z pohl'adu historickej vedy stáva skutočnou historickou udalost'ou s faktickým dopadom na človeka a spoločnost'.

Problematikou fikcie sa zaoberá aj psychológia (či dokonca psychiatria). $V$ psychológii osobnosti je imaginácia a fantázia ponímaná ako forma obrany proti ohrozeniu stability hlbokých štruktúr osobnej iden-

\footnotetext{
${ }^{6}$ Uvedené citáty a súvislosti pozri: ECO, Umberto: Od hlouposti $k$ šílenství. Zprávy o tekuté společnosti. Praha : Argo, 2016, s. 119 ,127. Citát znie v originále: „Das Geheimnis gibt der Persönlichkeit eine Ausnahmestellung, es wirkt als ein rein sozial bestimmter Reiz, prinzipiell unabhängig vom Inhalt, den es hütet, aber natürlich in dem Maße steigend, in dem das ausschließlich besessene Geheimnis bedeutsam und umfassend ist [...] wirken dem Unbekannten gegenüber zu dem gleichen Ziel, es durch die Phantasie zu steigern und ihm eine Aufmerksamkeit sbetonung zuzuwenden, die die offenbarte Wirklichkeit meistens nicht gewonnen hätte." SIMMEL, Georg: Soziologie. Untersuchungen über die Formen der Vergesellschaftung. Leipzig : Verlag von Duncker \& Humblot, 1908, s. 360 (kapitola Das Geheimnis und die geheime Gesellschaft). Dostupné na internete: <https://www.ssoar.info/ssoar/handle/document/54620> [Cit. 2020-06-02]. Aby bolo možné správne porozumiet' tomuto komplikovanému citátu, je potrebné preložit' ho vol'ne. Možný je aj nasledujúci preklad: Tajomstvo poskytuje osobnosti výnimočnost' a predstavuje sociálne podmienenú škálu podnetov, je v princípe nezávislé od obsahu, ktorý chráni, rozširuje sa však celkom prirodzene v množstve, pričom disponuje výlučnost'ou, má svoj význam a je komplexné... ciel’om je vygradovat' neznáme prostredníctvom fantázie a pritiahnut' k nemu pozornost', ktorú by väčšinou zjavná skutočnost' nedokázala vzbudit'.
} 
tity človeka. Fantázia (fikcia) môže vyjadrovat' potlačené priania. Zároveň však ide o spôsob vyrovnávania sa so zmenami a modifikáciami, s ktorými sa človek poča života stretáva. ${ }^{7}$ Fikcia môže byt' okrem psychologického mechanizmu adaptácie na zmeny aj hrou, ktorej poslaním je zlepšovat' analogického myslenia a kreativity, čo tiež reprezentuje mechanizmus psychologickej adaptácie. Uvažovanie o fikcii podnecuje človeka k tomu, aby sa učil mysliet' kriticky a hl'adal logické zdôvodnenia pre svoje myšlienkové závery a skutky.

Špecifický prístup k fikcii má literárna veda, resp. vedy o výtvarnom umení. Vo vede o literatúre sa hovorí o fikčných svetoch, teda svetoch literárnych diel, ktoré nemajú priamu referenciu k skutočnosti, no otvárajú nové možnosti reálneho bytia tým, že vytvárajú analógie medzi textom a realitou a medzi autorom textu a čitatel'om. Z toho vyplýva, že fikčné svety, hoci v súčasnosti neexistujú, je možné reálne vytvorit'. Ponúkajú nové možnosti a alternatívy bytia a sú charakteristické imagináciou odvíjajúcou sa od skutočného sveta. Odkazujú na to, ako sa udalosti mohli stat' alebo ako by sa mohli odohrat'. ${ }^{8}$ Hoci Slovník súčasného slovenského jazyka pozná iba slovo fiktívny vo význame spočívajúci vo fikcii, v skutočnosti neexistujúci, vymyslený, v spomenutých vedách, predovšetkým bádaniach o literatúre, filme a divadle sa používa aj adjektívum fikčný. ${ }^{9}$ To označuje entity, ktoré síce v danom momente neexistujú, no ich existencia je možná. Prídavné meno fiktívny sa skôr vzt'ahuje na vymyslené skutočnosti, pričom sa primárne neuvažuje o ich vzt'ahu k skutočnosti a realizácii. Ide o číru fantáziu. Medzi používaním jednotlivých pojmov je preto potrebné rozlišovat'.

\section{Literárna fikcia}

V spojitosti s Kremnicou a fikciou viazanou na literárne dielo treba pripomenút' predovšetkým príklad známeho básnika, filológa a bádatel'a v oblasti archeológie, etnografie a folkloristiky Jána Kollára. S Kremnicou ho spájalo štúdium na tunajšom nižšom evanjelickom gymnáziu (1806 1809). Cestou domov zo štúdií na univerzite v Jene nadviazal v Prahe kontakty s J. Dobrovským, V. Hankom a J. Jungmannom a v Bratislave

\footnotetext{
${ }^{7}$ NAKONEČNÝ, Milan: Psychologie osobnosti. Praha : Academia, 1995, s. 189, 190.

${ }^{8}$ MAGÁLOVÁ, Gabriela: Fikčné svety - referencia prvého a druhého radu. In: MAGÁLOVÁ, Gabriela: Slovenský jazyk v primárnom vzdelávaní 2. Trnava : Pedagogická fakulta Trnavskej univerzity v Trnave, 2013. [online]. Dostupné na internete: <http://pdf.truni.sk/eucebnice/sjvpv2/data/c879a40d-744f-4f01-82a9-d9c4ee4ea78e.html?ownapi=1> [Cit. 2020-06-11].

9 BUZÁSSYOVÁ, Klára - JAROŠOVÁ, Alexandra: Slovník súčasného slovenského jazyka A - G. Bratislava : Veda, vydavatel'stvo Slovenskej akadémie vied, 2006, s. 974. Fikcia = umelo vytvorená predstava, zdanie, výmysel, uplatnenie fantázie v rozprávaní príbehu; fikcia existuje aj v právnej teórii (právna domienka na súde v rozpore so skutočnost’ou).
} 
s F. Palackým (1819). Kollár bol prívržencom slovanskej vzájomnosti a česko-slovenskej jazykovej jednoty (písal v slovakizovanej češtine). ${ }^{10}$

Ján Kollár bol tvorcom ideológie slovanskej jednoty. V rámci svojich bádaní navštívil aj severné Taliansko, kde počas dvoch študijných ciest v rokoch 1841 a 1844 hl'adal stopy po staršom slovanskom osídlení. Publikačným výstupom z týchto ciest boli dve diela, a to Cestopis obsahujíci cestu do horní Italie a odtud přes Tyrolsko a Bavorsko, se zvláštním ohledem na slavjanské živly roku 1841 (1843) a posmrtne vydaná Staroitalia slavjanská (1853). Kollár sa v Taliansku popri štúdiu pamiatok antiky a renesancie zaoberal najmä výskumom slovanstva - jeho osídleniu, jazyku a pamätihodnostiam. Pritom využíval, tak ako to konštatoval Zdeněk Hrbata, „syntézu myšlienok, faktov, pamiatok, súdobých znalostí, vágnych stôp a imaginárnych prvkov“. Pomocou filológie a etymológie pátral po slovanských názvoch, menách a ich koreňoch. Napríklad o Benátkach (Venezia) predpokladal, že ich založil slovanský kmeň Venedov (Veneto-Slávi). Podobne fantasticky považoval za ich staré sídlo aj Miláno (Medulán). O Slovanoch tvrdil, že v tejto oblasti žili už pred Keltami. ${ }^{11}$ V historiografii sú tieto pokusy chápané ako produkt fantastiky (hoci sú Kollárove národnoobrodenecké zámery pochopitel'né) a nevedeckej metodiky zo slovanskej archeológie a etnografie. Autorovo etymologizovanie stojí na nekritických základoch (za slovanský jazyk považuje dokonca už latinčinu). Pavol Jozef Šafárik označil jeho postupy za „učenú fantastiku“. Historici však zároveň upozorňujú na to, že význam Kollárovho diela nespočíva vo vede, „ale v koncepcii slovanstva a v literárno-umeleckej tvorbe, ktorá odzrkadl'uje národné a slovanské myslenie českej a slovenskej obrodeneckej spoločnosti dávajúc mu myšlienkový systém."12

Vzhl'adom na tému fikcie sú Kollárove práce viažuce sa $\mathrm{k}$ „hornej Itálii“ exemplárnym príkladom využitia literárnej fikcie vo „vedeckom“ diele. Ján Kollár s nadšením prijal napríklad aj „objav“ staročeských rukopisov zelenohorského a královedvorského (1817), ktoré ako fikcia

\footnotetext{
10 Ján Kollár (1793, Mošovce - 1852, Viedeň) V rokoch 1806 - 1809 študoval na nižšom evanjelickom gymnáziu v Kremnici (1806 - 1809). Neskôr Kollár absolvoval štúdiá na gymnáziu v Banskej Bystrici, lýceu v Bratislave a univerzite v Jene (štúdium teológie $\mathrm{v}$ rokoch 1817 - 1819). Potom až do roku 1849 pôsobil ako kazatel' a farár slovenskej evanjelickej cirkvi v Pešti. Posledné tri roky života bol profesorom slovanskej archeológie na univerzite vo Viedni. MAŤOVČíK, A. et al.: Slovenský biografický slovník (od roku 833 do roku 1990). III. zväzok. Martin : Matica slovenská, 1989, s. 145.

${ }^{11}$ HRBATA, Zdeněk: „Slavovlašská“ Itálie a „naši předci Galové“. Komparativní pohled na některé konstrukty slovanománie a keltománie. In: HRDINA, M. - PIORECKÁ, K. (eds.): Historická fikce..., s. 146, 150-151.

12 KUTNAR, František - MAREK, Jaroslav: Přehledné dějiny českého a slovenského dějepisectví. Od počátků národní kultury až do sklonku třicátých let 20. století. Praha : Nakladatelství Lidové noviny, 2009, s. 251-252.
} 
mali potvrdit' to, že česká národná (teda slovanská) kultúra siaha hlboko do stredoveku. Dokonca na královedvorský rukopis Kollár zložil ódu:

\section{KRÁLOVODVORSKÝ RUKOPIS ${ }^{13}$}

Řek má Homéra, s bardy si hrá Němec,

kde Hekla soptí, tamt' Osian zněje:

Jen náš uchem vnuk darmo bystrým

háje němé Slovanů nasléchá.

Vy, věštci dávní, jimž zvuky Bůh v jazyk

kládl, by svou vy v ně ste duši vdechli;

jenž ste prvý hláhol slovanský

$v$ šat století vinuli - kde pak jste?

...

Ha, co slyším tam králova od hradu?

Prst z oblaků ční, ted', vece, jsou cosi:

Patřím a ve mlhe zmizlo heslo:

Př́teli! príteli! Tam ta pod'me.

Zde jsou, zde! v krásném, viz hle, leží hrobě;

smích jich-li temné tknouti se zástèry?

Aj, tak sloní mi truhlu záré,

$v$ níž s varytem svazeček zpěvů bdí.

...

Vzhưru pocit'tež, pěstověků spalí

Čestmíre, Oldro, Zaboji, Jarslave! ${ }^{14}$

Vás, slyšte, vás k padlé měděnný

vlasti jazyk věže této kř́sí.

...

I vy, kdo svých jste, starci, bohů haslé

ohniště uzř́c zoufali, vrat'te se:

Novou založme z těchto dávné

si zbořenin vzdelanosti pevnost.

Jána Kollára možno označit’ za čistokrvného literáta a až sekundárne za vedca. Jeho literárna činnost’ ho úzko viazala k literárnej fantastike. Je zjavné, že mal bohatú predstavivost' a obrazotvornost'. A bolo tomu

\footnotetext{
${ }^{13}$ KRAUS, Cyril: Slovenský klasicizmus. Poézia. Bratislava : Slovenský Tatran, 2004, s. 207-208. ${ }_{14}$ Čestmír, Oldřich, Záboj a Jaroslav sú názvami básní v královedvorskom rukopise. V nich sa popisujú bájne skutky týchto mýtických fiktívnych postáv (s výnimkou kniežat’a Oldřicha).
} 
tak už od detstva, ako to dokazujú aj jeho študentské roky strávené v Kremnici. Vo svojich pamätiach prezentoval zaujímavú schopnost' „vymýšl'at' a rozprávat' rozprávky bez akejkol'vek prípravy". Popísal to takto: „U pani Špánikovej [v Kremnici - pozn. D. H. K.] bývalo nás druhý rok asi 10 žiakov. Večer potme i v posteli v noci rozprávali sme si obyčajne rozličné rozprávky. Temer každý zo žiakov vedel mnoho takýchto rozprávok, ktoré počúval v detstve, iba ja nie [...] Jednako, nechcel som sa dat' zahanbit' alebo predstihnút'. Vypomohol som si vlastnou obrazotvornost'ou: vymýšl'al som si rozprávky, nikdy predtým neslýchané. A nedal som na sebe znat', že ich sám skladám, ale vyhlasoval som ich za staré. Spolužiaci, počúvajúc tieto nové veci o tvoroch, potvorách, o krajoch a príbehy, pozliezali z postele, obkl'účili moje lôžko a vel'mi pozorne nastavovali uši [...] Rozprával som o akejsi zelenej kačici, o bezdnom jazere, ktorého vody siahali až na druhú stranu zeme, o začarovanom zámku a bohvie ešte o čom, kam práve chvíl'ka zaniesla moju mysel." "15 Predstavivost' Jána Kollára bola teda už vo veku 13 - 14 rokov plná fiktívnych príbehov a postáv.

V rámci témy literárna fikcia možno uviet' aj príklad spisovatel'a, učitel'a a redaktora Jozefa Cígera Hronského. ${ }^{16}$ Popri prozaickej tvorbe pre dospelých sa venoval aj tvorbe literatúry pre deti a mládež. V Kremnici založil spolu s J. Kejzlarom edíciu kníh Mládež, v rámci ktorej vyšli štyri jeho knižky - Najmladší Závodský, Kremnické povesti, Janko Hrášok a Pod kozúbkom. V literárnej práci Hronský využíval fikciu. Jeho Kremnické povesti (1924) sú plné fiktívnych literárnych postáv mytologického charakteru - rohatý človek, kremnický obor (Kovoklad), horský duch, vodná víla, št'astlivý pastier, čierny rytier, zlatnícky učeň, strigy, čertova nevesta, trpaslíci atd'. ${ }^{17}$ Aspoň na okraj uved'me, že jeho najznámejšia literárna postava Jozef Mak patrí takisto k fiktívnym románovým hrdinom. V rovnomennom románe z roku 1933 využil Hronský literárne postupy realizmu kombinované s naturizmom a vytvoril psychologický prototyp Jozefa Maka, pasívneho človeka odovzdaného osudu. Je pozoruhodné, že táto fiktívna postava sa dostala aj do bežnej slovenskej frazeológie (Jozef Mak - človek milión) a l'udia o „jozefmakovčine“ hovoria dodnes. ${ }^{18}$

\footnotetext{
${ }^{15}$ KOLLÁR, Ján: Pamäti z mladších rokov života. Liptovský Mikuláš : Tranoscius, 1997, s. 55. 16 Jozef Cíger Hronský (1896, Zvolen - 1960, Luján, Argentína) študoval na učitel'skom ústave v Leviciach. Pôsobil ako učitel' na l’udových školách v Horných Mladoniciach (1914), Senohrade (1916 a 1917), Krupine (1920 - 1923) a v Kremnici (1923 - 1927). Po presídlení do Martina vyučoval na tamojšej meštianskej škole (1927 - 1933) a pracoval v Matici slovenskej (ako jej tajomník 1933 - 1940 a správca 1940 - 1945). Po druhej svetovej vojne emigroval cez Taliansko do Argentíny. VALENTOVIČ, Š. et al.: Slovenský biografický slovník (od roku 833 do roku 1990). II. zväzok. Martin: Matica slovenská, 1987, s. 415 a 416.

${ }^{17}$ HRONSKÝ, Jozef Cíger: Kremnické povesti. Kremnica : Mládež, 1924.

${ }^{18}$ HRONSKÝ, Jozef Cíger: Jozef Mak, s. 206. Dostupné na internete: <https://drive.google. com/file/d/0BxUWyIJ63zl5S2Y0VkpoRndxUjQ/view> [Cit. 2017-03-20]
} 


\section{Fikcia ako hra a recesia}

Mnohé spolky a spoločnosti majúce za ciel' zábavu, hru a recesiu majú pôvod v 19. storočí. K najznámejším patria spolky Šlarafie (z nem. zem blahobytu), z ktorých najstarší vznikol v Prahe v roku 1859. Šlarafia sa neskôr rozšírila do d'alších, hlavne nemecky hovoriacich krajín a komunít, a to aj v zámorí. Základom recesie v sieti šlarafijských spolkov bola úcta k fiktívnej autorite, ktorú predstavoval výr (Uhu). Na jednej strane boli spolky ukotvené vo fiktívnom svetovom poriadku, na druhej v historizme (inšpirácia renesanciou, stredovekým rytierstvom, dvorskou literatúrou a šl'achtictvom - členovia prijímali fiktívne mená s predikátmi) s presahmi do nedávnej minulosti a súčasnosti (napríklad úcta k hudobným skladatel'om ako boli Mozart či Beethoven; založenie nového letopočtu - rok 1859 = 1 anno Uhui). Typická pre tieto spolky bola ceremoniálnost' i sakralita viazaná na mytológiu. Charakteristické boli takisto alúzie či persifláže na cirkevné obrady. ${ }^{19}$

Pritom je potrebné si uvedomit', že pri Šlarafii nešlo iba o kuriózne a recesistické prvky (pivné súboje, zosmiešňovanie kultúrnych vzorov), ale aj o to, že ich existencia vychádzala zo všeobecných antropologických potrieb 19. storočia ako to konštatoval vo svoje podnetnej štúdii Martin Pelc. Spolky Šlarafie mali pevné sociálne ukotvenie - ich členmi mohli byt' iba muži s určitým spoločenským postavením a dobrou povest'ou, ako aj s patričným vzdelaním (kultúrny rozhl'ad bol predpokladom porozumenia humoru v týchto spolkoch). Zároveň boli jednotlivé spolky začlenené do sociálnej siete ostatných spolkov usporiadaných do jednotlivých „ríš“. Pri obradoch v Šlarafiách išlo o hru (antropologický fenomén), pri ktorej nebola dôležitá sút’aživost', ale recesia, fikčná fantastika a mystifikácia. Hra pritom nebola bezúčelová, ale mala svoje poslanie. Mircea Eliade konštatoval, že moderný človek žije v neohraničenom a neistom profánnom čase a čelí pádu do nekonečnosti času. Tejto nekonečnosti sa človek usiluje vzdorovat' viacerými prostriedkami. Jedným z nich je aj hra (M. Pelc), prostredníctvom ktorej sa človek vracia do sústredeného magického (posvätného) času. Hráč žije vo "fiktívnej skutočnosti“ (Roger Caillois). Hrou človek na jednej strane čelí každodennej skutočnosti (kompenzuje ju), na strane druhej prostredníctvom sakrality ukotvuje svoj život. To bol aj dôvod, prečo sa solídni muži v recesistických spolkoch venovali „nesolídnym“ aktivitám. ${ }^{20}$ „Prevrátené“ hodnoty sa v spolkovom živote strednej Európy vyskytovali často. Prostredníctvom vtipu a irónie sa členovia týchto

\footnotetext{
${ }^{19}$ PELC, Martin: Recesistické spolky Šlarafie. Herní prvek v kultuře 19. století. In: HRDINA, M. - PIORECKÁ, K. (eds.). Historická fikce..., s. 249-252.

20 PELC, M.: Recesistické spolky..., s. 252-256 (tu je uvedené aj spojenie „fiktívna skutočnost"' Rogera Cailloisa).
} 
spolkov vyrovnávali so sociálnou a politickou realitou života $\mathrm{v}$ habsburskej monarchii. ${ }^{21}$

Mimochodom, v zbierkovom fonde NBS - Múzea mincí a medailí Kremnica sa nachádza aj niekol'ko medailí s tematikou spolkov Šlarafie. Jednu z nich vytvoril nemecký medailér Adolf Schwerdt (Stuttgart). Na averze medaily je alegorická ženská postava so šašovskou (šlarafijskou) čiapkou kladúca veniec na hlavu druhej alegorickej ženskej postave v pokl'aku, vl'avo dole je výr sediaci na knihe. V kruhopise sú slová SCHLARAFFIA METIS 1585 a datovanie - anno Uhui 51 (1910). Na reverze je korunovaný štít s dvojkrížom a tromi výrimi hlavami a kruhopisné heslo IN ARTE VOLUPTAS (v umení je rozkoš). Medaila bola vyrazená z bronzu a postriebrená, jej priemer je $45 \mathrm{~mm}$. Podl'a čísla 1585 by malo íst' o Šlarafiu vo Viedenskom Novom Meste. Druhá z medailí je českého pôvodu, viaže sa k Prahe. Na averze má v gotickej kružbe výra, šlarafijskú čiapku a čašu, kruhopis znie: SCHLARAFFIA IN ARTE VOLUPTAS. Na reverze je v kružbe lýra a vavrínová vetvička. Text v páske a stuhe hovorí o tom, že ide o záslužnú medailu z roku 1874. Medaila je bronzová a jej priemer je $42 \mathrm{~mm}$. Tretia medaila bola vyrazená pri príležitosti 40. výročia založenia prvej Šlarafie v Prahe (1859 - 1899). Na averze má plastické poprsie muža s fúzmi, šlarafijskou čiapočkou a v obleku s výrom, kruhopis sa týka spomenutého výročia. Na reverze je trojriadkový text: Allschlaraffia ihrem glorreichen Führer (celá Šlarafia svojmu slávnemu vodcovi). Medaila bola vyrazená z bronzu a má priemer $75 \mathrm{~mm} .{ }^{22}$

Českým ekvivalentom Šlarafií boli „spolky kosů“ (drozdov), pričom jednotlivé spolky tejto siete sa označovali ako hniezda (prvé, tzv. prahniezdo vzniklo v Chrudimi). ${ }^{23}$ Pozoruhodné je, že podobná spoločnost' vznikla aj v Kremnici, a to v rámci Kasína (Casino), ktoré malo spoločenský a kaviarenský charakter. Povestnými sa stali najmä jeho sobotňajšie schôdzky organizované na prelome 60 . a 70. rokov 19. storočia. ${ }^{24}$ V Kasíne vtomto období vznikol aj spolok „vtákov močarín“ (Sumpfvögel). V Štátnom archíve v Kremnici sa zachovala z roku 1872 kniha žartovných, prevažne pijanských zápisov tohto spoločenstva, tzv. Kniha močarín (Sumpfbuch). Čo sa týka frazeológie, bolo by v tomto prípade možné hovorit' v slovenčine o "kamarátoch z mokrej štvrte“

\footnotetext{
${ }^{21}$ MANNOVÁ, Elena: „Mužský svet“. Spolky a armáda v 19. storočí. In: SEGEŠ, Vladimír ŠEĎOVÁ, Božena (eds.): Miles semper honestus. Zborník štúdií vydaný pri príležitosti životného jubilea Vojtecha Dangla. Bratislava : Vojenský historický ústav, 2007, s. 123.

22 NBS - Múzeum mincí a medailí Kremnica, fond medailí, pr. č. 2003/0697, 2003/0698 a 2014/0466.

${ }^{23}$ PELC, M.: Recesistické spolky..., s. 249-250.

${ }^{24}$ LAMOŠ, Teodor: Archív mesta Kremnice. Sprievodca po fondoch a zbierkach. Bratislava : Slovenská achívna správa Povereníctva vnútra, 1957, s. 137-138.
} 
(pijanoch). Kniha močarín je písaná prevažne v nemeckom jazyku, no nachádza sa v nej aj jeden slovenský a jeden mad’arský zápis. Aké bolo poslanie spolku a spisovania zápisov, uvádza sa v úvode ku knihe: „[...] ide o nenahraditel'nú príručku pre všetkých vtákov močarín (Sumpfvögel), ktorá aj ,nemočinárom' do dvadsiatichštyroch hodín odhalí, ako sa stat' močiarnym vtákom [...] ako vrecková nápomocná kniha a so zretel'om na praktickú formu dostala odo mňa dolu podpísaného primerané meno ,vták močarín vo vrecku vesty'. Kniha obsahuje nielen rôzne produkty ducha talentovaných močarinných vtákov, a to vo forme obrazu, básne alebo všeobecnej prózy, ale aj systematiku močarinového živočíšstva, začínajúc po poradí od ropuších ikier až po nanajvýš pozoruhodného a nami vytvoreného král'a močarín [...] s rýdzim úctivým klepotom Bocian, 3. 10. 1872." 25 Tak ako tomu bolo pri spolkoch Šlarafie, aj pri kremnickej spoločnosti si jej členovia dávali fiktívne recesistické mená. V knihe je aj malý zoznam niektorých členov spolku obsahujúci tak hodnosti, fiktívne vtáčie prezývky, ako aj k nim priradené občianske mená: král' močariny - tantalus nenásytný - A. Klosska, vardajn močariny - bocian - Hermann Kunz, pisár močariny - volavka - A. Mayer, kantor močariny - ibis - J. L. Bella (známy slovenský skladatel'), Cicero močariny - plameniak červený - C. Tuczek, advokát močariny - vtákopysk - Gyurgyik, vták močariny - žeriav - Hans Bühler. ${ }^{26}$ Na ukážku odcitujme dva konkrétne zápisy: „Močarina, 12. november 1872 - 12. novembra sa rozhodli zídení močarinoví vtáci zagratulovat' prezidentovi Spojených štátov amerických kjeho znovuzvoleniu do funkcie, predsedajúcemu Tantalovi sa uložilo v mene novej republiky Sumpf (močarina) telegrafovat' nasledovné: ,Prezident Grant, New York, prezident močariny zasiela kolegovi srdečné šrum, Tantalus', uvedená depeša bola na doručenie odovzdaná Krokodílovi, Volavka. "27 Druhý zápis je slovenskou recesistickou básňou ${ }^{28}$ :

Hurra! Bratia! Chyt'me sa pohára!

Pime tú vlahu otca Gambrina,

Pivo to žitiu nebe otvára -

Sem pivo! Sem sa švárna dievčina.

Sumpf! Močarina! je naše heslo,

\footnotetext{
25 Štátny archív Banská Bystrica (d’alej ŠA BB), pracovisko Archív Kremnica (d’alej p. AK), fond Kremnické Kasíno, Sumpfbuch z roku 1872, nestránkované (Vorwort - predslov).

26 ŠA BB p. AK, fond Kremnické Kasíno, Sumpfbuch z roku 1872, nestránkované (Verzeichniss sämtlich vorhandenen „Sumpfgethieres“ - nasleduje za predslovom).

27 ŠA BB p. AK, fond Kremnické Kasíno, Sumpfbuch z roku 1872, nestránkované (zápis z 12. novembra 1872).

${ }_{28}^{2}$ ŠA BB p. AK, fond Kremnické Kasíno, Sumpfbuch z roku 1872, nestránkované (jediný slovenský zápis Hurra! Bratia!...).
} 
Kto chce slávne žit' - stane medzi nás!

Už ked'sme v „sumpfe“ - treba nám veslo -

A to je myslím pívový pohár.-

Tak pime bratia - pime do rána,

Zakopme starost'; mladost' ta chce žit' -

Já som - jak ríman vraví, len málá „rana“

No lež držím sa toho: len vždy pit'!-

Kňežovič, Kampfhan ${ }^{29}$

V nemeckom prostredí Kremnice na začiatku 70. rokov 19. storočia vznikol spolok, ktorý bol príbuzný Šlarafiám i českým spolkom drozdov. Išlo v ňom o zábavu a recesiu, no takisto, ako pri iných spoločnostiach aj o hru, pri ktorej mala dôležitú úlohu fikcia a mystifikácia a ktorá mala aj svoj sakralizujúci rozmer.

So symbolikou, zábavou a recesiou sa však v Kremnici možno stretnút' aj v staršom období. Zaujímavým je príklad z 18. storočia. Typickou pre banské mestá bola mytológia banských duchov (Berggeist) - ich personifikáciou boli fiktívni banskí démoni, piadimužíci, škriatkovia a permoníci (z nemeckého Bergmännlein). Najstaršia písomná zmienka o permoníkoch sa viaže k roku 1487 (Schneeberg). Výzor týchto mytologických postáv popísal už Georgius Agricola v diele Bermannus sive de re metalica $\mathrm{z}$ roku 1530. Opisuje ich ako tri piade vysokých mužíčkov, oblečených do dlhej banskej haleny (s kutňou) prepásanej opaskom a ošliadorom (banskou kožou) prekrývajúcim stehná. ${ }^{30}$ Viera v existenciu banských duchov sa oslabila v 18. storočí. Permoníci prestávali strašit' (ale aj pomáhat') a zaradili sa k symbolickej výbave banských miest, stali sa predmetom hier, zábavy a neskôr aj recesie. Zaujímavým spôsobom bola využitá permonícka tradícia počas návštevy cisára Františka Lotrinského v Kremnici v roku 1751. Po vstupe panovníka na námestie ho pred komorským domom privítali zástupcovia banskej správy a duchovenstva. Cisára obdarovali zlatou rudou. To sa udialo pozoruhodným spôsobom. Rudu mu podal permoník (banský trpaslík - Berg = Zwerch), ktorého zdvihol do výšky panovníka sediaceho na koni jeden z dôstojníkov (Flügelmann). ${ }^{31}$ Kto však bol oným permoníkom? Ušitie šiat pre neho stálo komorskú správu 11 zlatých a 28 1⁄2 grajciara, čo

\footnotetext{
${ }^{29}$ Kampfhan = bojový kohút.

${ }^{30}$ HEILFURTH, Gerhard: Bergbau und Bergmann in der deutschsprachigen Sagenüberlieferung Mitteleuropas. Band I - Quellen. Marburg : N. G. Elwert Verlag, 1967, s. 103, 107 a 113.

31 ŠA BB, pracovisko Archív Banská Štiavnica, fond Mestský magistrát Banská Štiavnica, Protokol mesta Banskej Štiavnice z roku 1751 - na konci protokolu je pripojený popis pobytu cisára v stredoslovenskej banskej oblasti, s. 61 (dodatočné číslovanie v rámci uvedeného popisu).
} 
bola pomerne vysoká suma. ${ }^{32}$ Totožnost' permoníka pomohol odhalit' zápis v kremnickom kuriálnom protokole (kniha zápisov zo zasadnutí mestskej rady) z roku 1751. Pri 17. auguste tohto roku je uvedené, že permoníka predstavoval Lorenz Daubner zo Skleného (dedina v Turci patriaca Kremnici) a že cisársky radca a maršal gróf Jozef Esterházi požiadal o jeho vyslanie do Viedne, kde ho do konca života hmotne zabezpečí. ${ }^{33} \mathrm{Z}$ uvedeného vyplýva, že Lorenz Daubner bol s vel'kou pravdepodobnost'ou liliputánom. Gróf Esterházi ho iste chcel mat' na svojom dvore ako kuriozitu, ktorú hodlal využívat' v rámci spoločenského života na dvore (hry, zábava, „recesia“).

\section{Fikcia ako forma edukácie}

Zaujímavým dokladom využitia vzdelávacieho potenciálu fikcie je kniha Pictorissa Cremniciensis z roku 2004 od historičky umenia Barbary Balážovej pochádzajúcej z Kremnice. ${ }^{34}$ Kniha sa skladá z troch častí. Prvá, denníková kapitola je, ako uvádza autorka na záložke knihy, „fiktívnym pohl'adom jednej ženy, Johanky Emerencie Rothenstein na sklonku jej života (v roku 1723 mala 67 rokov), manželky maliara a snád' i maliarky [...] konštruované denníkové záznamy tejto skutočnej postavy striktne vytvorené na podklade reálnych pramenných materiálov zoznámia čitatel'a s rôznorodými udalostami ovplyvňujúcimi a podmieňujúcimi osudy l'udí, zvlášt' meštianskych maliarov a sochárov raného novoveku [...] “.35

V záznamoch sú doložené historické fakty vsadené do určitej dejovej schémy, ktorá pútavou formou približuje čitatel'ovi život ranonovovekej spoločnosti. Všetky v nich vyskytujúce sa postavy sú pramenne doložené (v knihe je bohatý poznámkový aparát), dostávajú sa však do určitých čiastočne vyfabulovaných vzt'ahov v rámci každodenného života. V denníkovom zápise vystupuje napríklad konkrétny maliar a pojednáva sa $v$ ňom o jeho konkrétne doloženom alebo dodnes existujúcom výtvarnom diele, no to, že si ho objednávatel' objednal u umelca vo svojom dome v určitý deň a v určitú hodinu, a pritom ho domáca pani ponúkla pomarančmi, je fikciou či polofikciou. Jej úlohou je prostredníctvom vnemov a pocitov priblížit' čitatel'ovi život umelca $\mathrm{v}$ danom období. Mimochodom, to že sa v tom čase vskutku jedli aj exo-

\footnotetext{
32 KAŠIAROVÁ, Elena - SÍKOROVÁ, Elena: Finančné náklady spojené s cisárskou návštevou Banskej Štiavnice a Kremnice v roku 1751. In: KOWALSKÁ, Eva - ČELKOVÁ, Mária (eds.): Zlatá a strieborná cesta cisára Františka Štefana Lotrinského po stredoslovenských banských mestách - Die goldene und silberne Reise des Kaisers Franz Stephan von Lothringen in die mittelslowakischen Bergstädte. Banská Bystrica : Merkantil, 2001, s. 122-123. 33 ŠA BB p. AK, fond Mestské úradné knihy 1490 - 1923, Kuriálny protokol z rokov 1747 1752, s. 610.

${ }^{34}$ BALÁŽOVÁ, Barbara: Pictorissa Cremniciensis. Bratislava : [vlastným nákladom], 2004.

${ }^{35}$ BALÁŽOVÁ, B.: Pictorissa Cremniciensis, záložka na obale knihy.
} 
tické pomaranče je takisto $\mathrm{v}$ Kremnici pramenne dokladované. Pre názornost' z knihy zacitujme: „Rok 1728. 15. februára. Popoludní sa tu zastavila pani jedného z kremnických mešt'anov, ktorá si objednala u môjho muža zhotovenie podobizne. Hoci už nie je najmladšia, chcela by byt' vyobrazená v parádnych vyšivaných brokátových šatách s hlbokým výstrihom, aké sa v Kremnici vonkoncom nenosia, ale presne také vraj videla pri svojej ostatnej návšteve Viedne." K záznamu sa viaže očíslovaná poznámka: „Typ ženského meštianskeho portrétu prvej tretiny 18. storočia $v$ Kremnici ilustratívne reprezentuje portrét neznámej ženy z Amonovskej rodiny, $N B S-M M M, p$. č. 187/71.“36

V zápisoch sa uvádzajú z vel'kej väčšiny mená skutočných historických postáv. V uvedenom zázname z 15. februára 1728 sa spomína „pani jedného z kremnických mešt'anov." Ide teda o dve fiktívne postavy, ale vlastne len na prvý pohl'ad, pretože obe reprezentujú objednávatel'ov konkrétneho umeleckého diela, ktoré je citované v uvedenej poznámke. Tieto postavy nie sú teda úplne fiktívne, skôr reprezentujú predpokladaných (s vel'kou mierou pravdepodobnosti) objednávatel'ov, ktorých mená nie sú doložené v prameňoch. Fiktívnymi tak zostávajú predovšetkým určité vzt'ahy, vykreslenie prostredia a situácie. To všetko má svoj účel lepšie porozumiet' danej dobe a aktivitám výtvarnej komunity v Kremnici.

Z vedeckého pohl'adu by sa takto poňatá kniha blížila skôr literatúre faktu, resp. historickej beletrii. Monografia Barbary Balážovej má však aj d'alšie dve časti. Opät' citácia zo záložky: „Život a dielo dvanástich kremnických barokových umelcov odhal'ujú malé biografie v d'alšej, druhej časti knihy, pričom záznamy o niektorých, doteraz celkom neznámych menách poskytujú množstvo priestoru pre d'alší, osobitne umeleckohistorický výskum. Úlohou tretej časti knihy, vedeckej štúdie, by malo byt', nielen kunsthistorikovi, ale i zvedavému čitatel'ovi, vysvetlit' a na príkladoch ilustrovat' všetky predpoklady i triky, ako sa stat' úspešným človekom a umelcom $v$ štandardnej meštianskej spoločnosti raného novoveku našej krajiny. “37 Práve spojenie beletrizovanej kapitoly založenej na motívoch fikcie s biografickými medailónmi a vedeckou štúdiou robí knihu výnimočnou. Ak to zhrnieme, umožňuje pútavou, no zároveň vedecky artikulovanou formou preniknút' do života umeleckej komunity v Kremnici medzi rokmi 1723 - 1736. Vd'aka forme knihy môžeme vybranú historickú etapu uchopit' ovel'a plastickejšie. Na záver uved'me pre zaujímavost' názvy všetkých troch kapitol knihy Pictorissa Cremniciensis: 1) Johanka Emerencia Rothenstein, vdova, maliarka, asi 80-ročná, 2) Koho v Štiavnici neuväznia, v Bystrici neobesia a v Kremnici neoženia, ten

\footnotetext{
${ }^{36}$ BALÁŽovÁ, B.: Pictorissa Cremniciensis, s. 18 a 97 (pozn. č. 51).

37 BALÁžOVÁ, B.: Pictorissa Cremniciensis, záložka na obale knihy.
} 
môže hovorit' o vel'kom št’astí, 3) Sochári sú slobodní umelci a nevykonávajú žiadne remeslo.

\section{Fikcia ako súčast' národného príbehu}

Súčast'ou národnoobrodeneckých procesov v jednotlivých krajinách boli aj rôzne „objavy“ dokladajúce starobylost' toho-ktorého etnika. S fabuláciami týkajúcimi sa národných dejín sa stretávame po celej Európe. Zaujímavé sú české príklady. Z nich k najznámejším patrí objav rukopisov zelenohorského a královedvorského. Existujú však aj d'alšie prípady. Niektoré sa viažu dokonca už k 18. storočiu. Osvietenské myšlienky prepojené s romantickou konštrukciou vel'kého stredovekého českého majstra viedli k zrodu postavy gotického majstra Tomáša z Mutiny. Jeho diela boli datované do 13. storočia a malo íst' o najstaršie diela na svete mal'ované olejovými farbami. Údaj o Tomášovi sa dostal aj do diela Jána Kollára. V jeho Slovníku slavianskych umelcov všetkých kmeňov z roku 1843 sa o ňom píše, že je to „nejstarší slavný český malíř olejem“. Podl'a Kollára žil medzi rokmi 1250 - 1297. Ešte na konci 18. a začiatkom 19. storočia sa však ukázalo, že v prípade uvedených diel ide o talianskeho majstra Tommasa Barisiniho da Modena (1325/26 1379). Klasickým obdobím mystifikácií spojených s národným obrodením bolo 19. storočie, no príklady sa nájdu aj v 20. storočí. Napríklad Jakub Arbes popísal v poviedke Škrétův poslední souboj (1941) viacerých historických českých maliarov, z ktorých čast' dokonca ani neexistovala. K písomnej kultúre sa viažu súvisia objavy spisovatel'a a archeológa Václava Krolmusa, ktoré súviseli aj so staroslovanskými bádaniami Jána Kollára. Napríklad na nádobe objavenej v Drahelčiciach v roku 1858 rozpoznal staroindický text. Jeho najznámejším „objavom“ je však nález staroslovanskej modlitebne na jednom statku v Skalsku ned'aleko Mladej Boleslavi v roku 1852. V nej boli okrem iného aj dva kamene s runovými nápismi, ktoré mali odkazovat' na boha podzemia Černoboha. K definitívnemu vyvráteniu jeho teórie došlo v roku 1864 na základe expertízy Františka Beneša z Národného múzea v Prahe. ${ }^{38}$

Na Slovensku je podobných romantických objavov menej. Jeden z nich sa viaže k mestu Kremnica, resp. k vrchu Velestúr ležiacemu ned'aleko mesta $v$ Kremnických vrchoch. Ide o nápis na skale, ktorý mal byt' vysekaný do skaly v dávnej minulosti v runovom „slovenskom“ písme. Tento výklad s nadšením prijímajú rôzni laici, resp. historici - laici nadšenci, oficiálna historiografia má však jasný názor - nápis je falzifikátom, fikciou.

\footnotetext{
38 VLNAS, Vít: Slavní a vymyšlení - praotcové českého výtvornictví. Božetěch - Tomáš z Mutiny - Zbyšek z Trotiny. In: HRDINA, Martin - PIORECKÁ, Kateřina (eds.). Historická fikce..., s. 121, 122 a 127-131; LUTOVSKÝ, Michal: Archeologie 19. století. Ráj fikcí i peklo omylů. In: HRDINA, Martin - PIORECKÁ, Kateřina (eds.). Historická fikce..., s. 203-205.
} 
Z historikov sa kritickej analýze nápisu venovali najmä Michal Matunák, Vlado Uhlár a najnovšie i Patrik Fuzák. Nestor slovenskej historickej vedy, zvlášt' medievistiky, Richard Marsina napísal vo svojom príspevku o Matici slovenskej a počiatkoch slovenskej vedy nasledujúce slová: „V Letopise MS bola uverejnená prvýkrát aj správa Pavla Križka o (údajných) starobylých nápisoch na Kremnickom pohorí (o ktorých neskôr Michal Matunák dokázal, že sú modernými falzifikátmi) spolu s dodatkom od Jozefa Božetecha Klemensa, ktorý ich už nazýval „runoslovanskými“ (slovenskými runami); tzv. starožitným (antickým) nápisom sa venoval aj evanjelický farár v Hornej Lehote Samo Chalupka. Zrejme vtedy mladá slovenská historiografia tak, ako už o niečo skôr iné národné historiografie, musela aj týmto spôsobom splatit' svoju daň snahe po dokazovaní čo najväčšej starobylosti svojho národa.“39

Objavitel'om velestúrskeho nápisu bol kremnický učitel’ (neskôr historik a archivár) Pavol Križko. Svoj objav z roku 1864 prvýkrát publikoval v časopise Sokol v roku 1865, s prekladom textu prišiel v roku 1868. ${ }^{40}$ Sám sa síce neskôr vo svojom živote už $\mathrm{k}$ tomuto nápisu nevrátil a ani vo svojich najdôležitejších prácach z dejín Kremnice ho nespomenul, napriek tomu si téma nápisu našla medzi laikmi množstvo pokračovatel'ov brániacich rôznymi spôsobmi jeho autenticitu. V roku 2016 dokonca vyšla samostatná knižná publikácia Pravda o Velestúre tajné dejiny od Jána Ducára z Prešova, ktorá si za ciel' vytýčila obhájit' pravost' nápisu, interpretovat' ho, datovat' a očistit' meno jeho objavitel'a Pavla Križka, očierneného zmieneným kremnickým historikom Michalom Matunákom. Ako Ján Ducár napísal: „Účelové lži jeho neprajníka - mad'aróna Michala Matunáka (skrývajúceho sa v Matici slovenskej) o tom, že nápis vytvoril Križko (s pomocou Klemensa a Moravčíka) považujem za vykonštruovaný prejav pomsty za odhalenie plagiátorstva kuruckých piesní samotného Matunáka. Okrem toho je pamflet Matunáka proti Križkovi výrazom konfesionálnej pomsty (katolík Matunák proti evanjelikovi Križkovi), o čom sa do terajších dní medzi občanmi Kremnice stále živo rozpráva." Okrem toho spochybnil aj prácu historikov: „Poctivý (nestranný amatérsky) bádatel' sa dokáže pri objektívnom výskume dopracovat’ bližšie k pravde ako človek, ktorý počas štúdia archeológie alebo histórie na vysokej škole dostane okrem množstva naozaj pravdivých informácií aj tradované pravdy, informácie - stále a dookola prepisované ,fakty' zo starších učebníc, ktoré sa tvária ako pravdy, hoci sú

\footnotetext{
${ }^{39}$ MARSINA, Richard: Matica slovenská a počiatky slovenskej vedy. Dostupné na internete: <http://www.kultura-fb.sk/new/old/archive/13-3-17.htm> [Cit. 2017-03-16].

${ }^{40}$ KRIŽKO, Pavel: Dva novoodkryté starobylé nápisy na kremnickom pohorí. In: Sokol, roč. 4, č. 1, 1865, s. 11-12; KRIŽKO, Pavel. Starobylé nápisy na kremnickom pohorí. In: Letopis Matice slovenskej, roč. 5, č. 2, 1868, s. 75-96.
} 
často už modernou vedou vyvrátené." Zhrňme výsledky, ku ktorým dospel Ján Ducár vo svojej knihe. Velestúrsky nápis pokladá jednoznačne za autentický, v podstate súhlasí aj s Križkovým prekladom textu (udalost' v ňom popisovanú však kladie do roku 958). Na rozdiel od iných bádatel'ov, ktorí datovali nápis do 3. či 16. storočia, však na základe výskumov Jiř́ho Riegera z Mělníka prichádza s vlastným datovaním. Píše: „Ten, kto zostavil nápisy, nemohol byt' žiadny amatér. Velestúrska abeceda je najdômyselnejšia domáca abeceda vedl'a cyriliky. Čerpá nielen z italických abecied, ako z runovej abecedy, ale je doplnená i typmi z hlaholiky. Jej autorom musel byt' vzdelaný kňaz. Podl'a toho, že velestúrsky nápis obsahuje kalendárny kryptogram podl'a metód benediktínskych mníchov (vid' Kensingtonský runový kameň a iné runové severské nápisy), musíme uvažovat', že zostavovatel'om abecedy i nápisov bol mních benediktín. " Za autora textu považuje ostrihomského arcibiskupa Radlu - Astrika, ktorý do Uhorska prišiel so sv. Vojtechom a predtým bol opátom benediktínskeho kláštora v Břevnove a opátom kláštora v Pannonhalme. To datuje nápis do začiatku 11. storočia. Ján Ducár dokonca vidí v texte kryptogram Astrikovho mena. Vidí ho v prvom, druhom a šiestom písmene dvojíc písmen nachádzajúcich sa na začiatku prvých troch riadkov textu a v štvrtom riadku na jeho konci (M-P-D-A-A-S-T-R-I-CH) - teda Astrik zvaný v češtine aj „Bd'a“ (Bdící). Ján Ducár uzatvára: „Z pa-lindromu v Rukopise zelenohorskom vieme, že sa nazýval aj, Čuvatel", čo je to isté ako ,Bd'a“.41

Proti pravosti nápisu sa už pred takmer 90 rokmi postavil historik Michal Matunák. Poznatky k tejto problematike publikoval v monografii $Z$ dejín slobodného a hlavného banského mesta Kremnice z roku 1928. Matunák kritizoval v prvom rade skutočnost', že Pavol Križko sa pri preklade textu a jeho interpretácii opieral o dielo istého Jána Bolského Memorabilia septem montanarum civitatum z roku 1627. Také dielo však nikde nenašiel, takže prišiel k záveru, že si ho Križko vymyslel. Podl'a údajnej Bolského práce mala Kremnica bránit' od juhu bohaté mesto Eturum (Eburum) nachádzajúce sa v Turci. Toto mesto založil knieža Marahanov Thaur, čiže Tur (Tur = Turiec), neskôr v ňom vládol Conesius, zvaný Banius. V roku 280 n. l. však Eturum dobyli Silingovia (slovanského pôvodu). Tí nechali zbúrat' aj trojité opevnenie stojace pri Kremnici. Mimochodom, baníčit' v Kremnici sa malo začat' už v roku 770 , pričom v tom čase tu vládlo slovanské knieža Samomer. Pre úplnost' doplňme Križkov preklad nápisu na Velestúre: „Prišiel Silian od severu, sboril Kremnicu a Turov (Eturum) a všetky hrady, i bol rok po Turu dvestoosemdesiaty." Zhrňme d'alšie Matunákove argumenty proti

\footnotetext{
41 DUCÁR, Ján: Pravda o Velestúre. Tajné dejiny. Bratislava : Eko-konzult, 2016, s. 167-168 a 183 (na týchto stranách sú aj všetky uvedené citáty).
} 
autenticite nápisu. Jeho autorom mal byt' samotný Križko, ktorý pri preklade textu urobil gramatickú chybu - prvé slovo prěchach uviedol v 1. osobe jednotného čísla (prišiel som), aj ked' malo mat' podobu prěchaaše (prišiel). Matunák argumentoval tým, že zo žiadnej inej oblasti nie sú známe slovanské runové nápisy („prečo nie sú také runy na Devíne, Bratislave, Velehrade, Prahe, Krakove...") a nespomínajú sa ani v kremnickom archíve, ako aj tým, že Križko nápisy pred ním (ani vo svojich zrelých historických dielach) nikdy nespomínal. Proti pravosti nápisu mala byt' aj skutočnost', že bol vytesaný do trachytovej skaly, ktorá rýchlo zvetráva. Za „kresliča“ textu určil Matunák Jozefa Božetecha Klemensa, v pozostalosti ktorého sa zachovalo mnoho kresieb velestúrskeho nápisu a ktorý sám o nápise aj písal, a za jeho „rytca“ Karola Moravčíka (Moravtsika), obuvníka z Kremnice, pretože v jednej z kremnických záhrad bol kameň s podobným „runovým“ textom ako na Velestúre a pri ňom bolo vysekané Moravčíkovo meno. Matunák poukázal aj na to, že vrch sa pôvodne nevolal Velestúr (slovanské božstvo), ale Verešd'úr (z mad'arčiny). Podl'a neho vytvorili všetci traja spomenutí nápis „V rámci národnej horlivosti a romantizmu“, pričom boli inšpirovaní Jánom Kollárom a jeho dielom Staroitalia slavjanská (Križko otvorene napísal, že mu pomohlo pri bádaní). ${ }^{42}$

„Objavy" rôznych „starobylých" textov v národných jazykoch boli prirodzenou súčast'ou národného vývoja v 19. storočí. Pritom sa v nich vyskytovalo množstvo fiktívnych postáv a udalostí. V prípade velestúrskeho nápisu to boli kmene Marahanov a Silingov a kniežatá Tur, Conesius (zvaný Banius) a Samomer. Fiktívnou bola aj existencia ríše Turov (Eturum) a jej pád v roku $280 \mathrm{n}$. l.

Z historikov sa v nedávnej minulosti nápisu venoval Patrik Fuzák a vylúčil autenticitu nápisu. Takisto ako Michal Matunák, poukázal na spojitost' Križkových výskumov s Kollárovou Staroitaliou slavjanskou. Upozornil aj na skutočnost', že podl'a spisovatel'a Gustáva Kazimíra Zechentera Laskomerského (od roku 1868 pôsobil v Kremnici ako banský lekár, tam aj v roku 1908 zomrel) bol už na konci 19. storočia text slabo čitatel'ný. Podl'a jeho hypotézy je autorom nápisu Jozef Božetech Klemens, ktorý bol archeológom, paleografom, maliarom a sochárom v jednej osobe. Osobne sa priatelil s Václavom Hankom, „objavitel'om“ královedvorského rukopisu, a podiel'al sa aj na publikovaní správy o objavení runových falzifikátov českého vlasteneckého kňaza Václava Krolmusa na Skalsku (1852). Križko sa v rámci tejto hypotézy „stal pravdepodobne obet'ou romanticko-vlasteneckej nástrahy Klemensa“. Patrik

\footnotetext{
42 MATUNÁK, Michal: Z dejín slobodného a hlavného banského mesta Kremnice. Kremnica : Mesto Kremnica, 1928, s. 47-52.
} 
Fuzák uzavrel svoju štúdiu konštatovaním, že Klemens ani nemusel považovat' nápis za falzifikát, ale z jeho strany mohlo íst' skôr o rekonštrukciu možného písma našich predkov. ${ }^{43}$

Historická obec je plne presvedčená o falzifikácii nápisu na kremnickom Velestúre. Do budúcnosti však historikov čaká náročná úloha zosumarizovat' poznatky k nápisu, rozanalyzovat' ich a podat' definitívny vedecký dôkaz o jeho nepravosti.

\section{Záver}

Videli sme, že fikcia je charakteristická svojou „reálnou“ existenciou, ktorá ovplyvňuje l'udské myslenie a konanie. Pomocou nej je možné rozvíjat' tak predstavivost', ako aj analogické a logické myslenie a kreativitu. Nezanedbatel'ný je jej edukatívny rozmer. Fikcia má dôležitú úlohu v l'udskom živote - je možné využit' ju na rôzne pozitívne zamerané aktivity. Prirodzene, ako všetko, dá sa využit' aj v neadekvátnych konotáciách, napríklad na zosmiešňovanie, zavádzanie či komerčné využitie. Ako príklad uved'me kolekcie medailí razené v kremnickej mincovni v nedávnej minulosti. Medaily nechala razit' súkromná podnikatel'ská skupina. Išlo o súbory Vládcovia Slovanov z roku 2000, Nekorunovaní králi Slovenska z roku 2002, Údelné kniežatá vel'komoravské $\mathrm{z}$ roku 2002 a Predslovanskí panovníci takisto z roku 2002. Vyrazené boli zo zlata v hodnote jedno-, dvoj-, pät'- a desat'-dukátov. Na medailách sú fiktívne portréty „vládcov“, ktorí figurujú v neadekvátnych historických kontextoch. Napríklad, ako nekorunovaný král' Slovenska sa označuje magnát Matúš Čák Trenčiansky, ako vel'komoravská údelná vládkyňa nemenovaná dcéra Mojmíra II. a ako predslovanskí vládci na dnešnom území Slovenska Attila a Marcus Aurelius. ${ }^{44}$ Projekt mal čisto obchodné poslanie bez ohl'adu na fiktívnost's ním spojených tvrdení.

Pri prvotnom pohl'ade na dejiny Kremnice to vyzeralo tak, že tu nebude možné k problematike fikcie a fiktívnych postáv zozbierat' väčšie množstvo podkladového materiálu. Napokon sa však ukázalo, že aj malé mesto má čo ponúknut' v spojitosti s touto problematikou. V dejinách Kremnice sme sa stretli s tradičnou literárnou fikciou, fikciou majúcou edukatívne poslanie, s fiktívnymi postavami a spolkami, ktoré mali zábavný a recesistický charakter, ale aj špecifickým, osobitne spracovávaným problémom fikcie ako súčasti národno-emancipačných snáh.

\footnotetext{
${ }^{43}$ FUZÁK, Patrik: Nápisy na kremnických vrchoch. In: Acta historica Neosoliensia, tom. 3, 2000, s. 190, 191 a 193.

44 SOLEJ, Peter: Prehl'ad medailérskej tvorby kremnickej mincovne 1993 - 2002. Prešov : Victoria, 2002, s. 171-174, 200-202, 213-216, 230-232.
} 